Syntax Literate: Jurnal Ilmiah Indonesia p-ISSN: 2541-0849

e-ISSN : 2548-1398

Vol. 5, No. 6, Juni 2020

\title{
PENGARUH PENGETAHUAN INVESTASI, PERSEPSI RETURN, DAN MOTIVASI INVESTASI TERHADAP MINAT INVESTASI PADA GALERI INVESTASI SYARIAH BURSA EFEK INDONESIA IAIN BATUSANGKAR
}

\author{
Khairul Marlin
}

Institut Agama Islam Negeri (IAIN) Batusangkar

Email: khairulmarlin@iainbatusangkar.ac.id

\section{Abstract}

Establishment the Islamic Investment Gallery of Indonesia Stock Exchange (IDX) as a means of disseminating information and disseminating information about the capital market within the academic community, and is expected to increase knowledge and provide motivation to the academic community about the importance of investing, in addition to expecting returns to be received. The education and literacy activities carried out have succeeded in increasing the number of students who are investing in the Islamic Investment Gallery of IDX IAIN Batusangkar. This got an appreciation from the Indonesia Stock Exchange West Sumatra Representative Office in March 2020 as an Investment Gallery which gave birth to the highest number of investors during 2019 and an award as a gallery that successfully carried out the most educational activities during 2019. The purpose of this study was to determine the effect of investment knowledge, perceptions of return and investment motivation on student investment interests in the IIS Batusangkar BEI Islamic Investment Gallery. The type of research used is quantitative. Data collection techniques used were questionnaires. The results showed that investment knowledge had a significant effect on student investment interest, perceptions of return did not significantly influence investment interest and investment motivation had a very significant effect on student investment interest in the Islamic Investment Gallery of IDX IAIN Batusangkar.

Keywords: Knowledge, Return Perception, Motivation and Investment Interest

\begin{abstract}
Abstrak
Pendirian Galeri Investasi Syariah Bursa Efek Indonesia (BEI) sebagai sarana dalam penyebarluasan informasi dan sosialisasi tentang pasar modal di lingkungan civitas akademika, serta diharapkan dapat meningkatkan pengetahuan dan memberikan motivasi kepada civitas akademika tentang pentingnya melakukan investasi, disamping mengharapkan return yang akan diterima. Kegiatan edukasi dan literasi yang dilakukan berhasil meningkatkan jumlah mahasiswa yang menanamkan investasinya di Galeri Investasi Syariah BEI IAIN Batusangkar. Hal ini mendapat apresiasi dari Bursa Efek Indonesia Kantor Perwakilan Sumatera Barat pada Bulan Maret Tahun 2020 sebagai Galeri Investasi yang melahirkan jumlah investor terbanyak selama Tahun 2019 serta penghargaan sebagai galeri yang berhasil melaksanakan kegiatan edukasi yang terbanyak selama Tahun 2019.
\end{abstract}


Tujuan penelitian ini adalah untuk mengetahui pengaruh pengetahuan investasi, persepsi return dan motivasi investasi terhadap minat investasi mahasiswa pada Galeri Investasi Syariah BEI IAIN Batusangkar. Jenis penelitian yang digunakan kuantitatif. Teknik pengumpulan data yang digunakan adalah kuisioner. Hasil penelitian menunjukkan bahwa pengetahuan investasi berpengaruh secara signifikan terhadap minat investasi mahasiswa, persepsi return tidak berpengaruh secara signifikan terhadap minat investasi dan motivasi investasi berpengaruh sangat signifikan terhadap minat investasi mahasiswa di Galeri Investasi Syariah BEI IAIN Batusangkar.

Kata kunci: Pengetahuan, Persepsi Return, Motivasi dan Minat Investasi

\section{Pendahuluan}

Dunia investasi dan pasar modal selalu menjadi topik pembahasan menarik di era globalisasi seperti saat ini. Tidak hanya di negara maju, fundamental ekonomi terjadi juga di negara berkembang dengan ditandai banyaknya investasi dan pasar modal. Salah satunya Indonesia yang saat ini sudah mulai bergerak dalam bidang investasi dan pasar modal

Pasar modal dalam Undang Undang Nomor 8 Tahun 1995 menyatakan bahwa pasar modal adalah kegiatan yang bersangkutan dengan penawaran umum dan perdagangan efek, perusahaan publik yang berkaitan dengan efek yang diterbitkannya, serta lembaga dan profesi yang berkaitan dengan efek. Menurut (Yuliana, 2010) dengan adanya pasar modal, investor badan usaha maupun individu dapat menyalurkan kelebihan dana yang mereka miliki untuk diinvestasikan di pasar modal, dan para pengusaha dapat memperoleh dana tambahan modal untuk memperluas jaringan usahanya dari para investor yang berada di pasar modal.

Meningkatnya nilai perusahaan menjadi faktor peningkatan nilai pemegang saham ditandai dengan peningkatan investor yang melakukan investasi pada suatu perusahaan. Nilai saham yang tinggi menggambarkan nilai perusahaan yang tinggi. Hal ini dapat dijelaskan secara sederhana bahwa nilai perusahaan (value) adalah hutang (debt) ditambah modal sendiri (equity) (Sutira, 2018).

Pembelian aktiva keuangan secara langsung di pasar modal atau pasar uang dapat di investasikan secara langsung. Sedangkan investasi tidak langsung bisa dilakukan dengan membeli saham perusahaan yang terdaftar di Bursa Efek Indonesia (BEI).

Bursa Efek Indonesia (BEI) dalam rangka memperkenalkan pasar modal pada masyarakat terutama dunia akademik maka dibentuklah Galeri Investasi Bursa Efek Indonesia (BEI) di beberapa perguruan tinggi di Indonesia. Galeri Investasi BEI ini merupakan kerjasama antara BEI, Perguruan Tinggi dan Perusahaan Sekuritas yang diharapkan tidak hanya memperkenalkan pasar modal dari sisi teori saja akan tetapi juga prakteknya (idx.co.id).

Galeri Investasi BEI sebagaimana dikutip dari situs idx.co.id menyediakan real time information untuk belajar menganalisa aktivitas perdagangan saham, yang diharapkan dapat menjadi jembatan menuju penguasaan ilmu pengetahuan beserta 
prakteknya di pasar modal, serta menyediakan semua publikasi dan bahan cetakan mengenai pasar modal yang diterbitkan oleh Bursa Efek Indonesia termasuk peraturan dan Undang-Undang Pasar Modal. Galeri Investasi BEI diharapkan dapat saling memberikan manfaat bagi semua pihak sehingga penyebaran informasi pasar modal tepat sasaran serta dapat memberikan manfaat yang optimal bagi mahasiswa, praktisi ekonomi, investor, pengamat pasar modal maupun masyarakat umum di daerah dan sekitarnya baik untuk kepentingan sosialisasi dan pendidikan/edukasi pasar modal maupun untuk kepentingan ekonomis atau alternatif investasi.

Galeri Investasi Syariah Bursa Efek Indonesia (BEI) Institut Agama Islam Negeri (IAIN) Batusangkar merupakan galeri investasi syariah pertama di Sumatera Barat. Galeri investasi ini menjadi sarana bagi mahasiswa dalam penguasaan ilmu serta praktek tentang pasar modal. Untuk meningkatkan pengetahuan mahasiswa dalam mengenal pasar modal dan melakukan investasi Galeri Investasi Syariah Bursa Efek Indonesia (BEI) melakukan berbagai kegiatan literasi dan edukasi seperti sekolah pasar modal, edukasi dan sosialisasi pasar, modal, aktivasi investor, praktikum investasi, serta konsultasi riset/penelitian di bidang pasar modal. Selain itu, juga terdapat beberapa kegiatan partisipasi dalam kompetisi yang diikuti oleh mahasiswa baik tingkat provinsi maupun nasional. Dengan adanya kegiatan ini diharapkan akan menumbuhkan minat mahasiswa untuk melakukan investasi di pasar modal Galeri Investasi Syariah Bursa Efek Indonesia (BEI) Institut Agama Islam Negeri (IAIN) Batusangkar.

Kegiatan edukasi dan literasi yang dilakukan oleh Galeri Investasi Syariah Bursa Efek Indonesia (BEI) Institut Agama Islam Negeri (IAIN) Batusangkar dapat memberikan motivasi serta meningkatkan minat mahasiswa untuk melakukan investasi di pasar modal. Kegiatan yang dilakukan ini telah mendapat apresiasi dari Bursa Efek Indoensia (BEI) Kantor Perwakilan Sumatera Barat untuk kategori galeri dengan kegiatan edukasi terbanyak selama Tahun 2019 dan kategori galeri dengan jumlah investor terbanyak selama tahun 2019 (http://febi.Iainbatusangkar.ac.id/).

Investasi adalah menanamkan atau menempatkan aset, baik berupa harta maupun dana, pada sesuatu yang diharapkan akan memberikan hasil pendapatan atau akan meningkatkan nilainya di masa mendatang (Yuliana, 2010). Untuk meningkatkan minat dalam melakukan investasi perlu adanya pengetahuan tentang investasi tersebut. Pengetahuan akan investasi akan membantu seseorang dalam mengambil keputusan dalam berinvestasi.

Pengetahuan dasar mengenai investasi merupakan hal sangat penting untuk diketahui oleh calon investor. Hal ini bertujuan agar investor terhindar dari praktikpraktik investasi yang tidak rasional (judi), budaya ikut-ikutan, penipuan, dan risiko kerugian (Pajar \& Pustikaningsih, 2017). Hal ini sebagaimana yang diungkapkan oleh (Situmorang, Andreas, \& Natariasari, 2014) bahwa untuk melakukan investasi di pasar modal diperlukan pengetahuan yang cukup, pengalaman serta naluri bisnis untuk menganalisis efek-efek mana yang akan dibeli. Pengetahuan yang memadai sangat diperlukan untuk menghindari terjadinya kerugian saat berinvestasi di pasar modal. 
Penelitian-penelitian terdahulu juga menyebutkan bahwa minat berinvestasi dipengaruhi oleh pengetahuan investasi, seperti penelitian Albab Al Umar dan Zuhri (2019) yang menunjukkan bahwa pengetahuan berpengaruh signifikan terhadap minat mahasiswa untuk berinvestasi di pasar modal syariah. Selanjutnya penelitian (Pajar \& Pustikaningsih, 2017) menyatakan bahwa pengetahuan investasi berpengaruh terhadap minat berinvestasi di pasar modal pada mahasiswa FE UNY.

Minat berinvestasi saham syariah tentunya juga tidak terlepas dari informasi dan edukasi yang didapat sehingga memunculkan sebuah persepsi, hal ini karena berinvestasi di pasar saham syariah selain mendapatkankan return juga mengandung sebuah resiko. Persepsi return dan persepsi risiko tersebut yang akan berpengaruh terhadap minat seseorang untuk berinvestasi (Purboyo, Zulfikar, \& Wicaksono, 2019). Menurut (Trisnatio \& Pustikaningsih, 2018) persepsi terhadap return yaitu pandangan dan harapan seseorang terhadap keuntungan yang akan didapatkan ketika berinvestasi di pasar modal.

Persepsi return berpengaruh terhadap minat mahasiswa dalam berinvestasi, hal ini sesuai dengan penelitian (Tandio \& Widanaputra, 2016) yang menujukkan bahwa persepsi return mempengaruhi minat investasi secara signifikan. Begitu juga dengan penelitian Trisnatio dan Pustikaningsih (2018) menunjukkan hasil bahwa ekspektasi return berpengaruh positif dan signifikan terhadap minat investasi saham. Berbeda dengan hasil penelitian (Purboyo et al., 2019) yang menunjukkan hasil bahwa persepsi return tidak berpengaruh signifikan terhadap minat mahasiswa untuk berinvestasi di saham syariah. Begitu juga dengan penelitian (Nandar, Rokan, \& Ridwan, 2018) return investasi tidak memberikan pengaruh yang signifikan terhadap minat mahasiswa dalam berinvestasi di pasar modal syariah.

Motivasi seseorang juga akan mempengaruhi minat investasi. Motivasi investasi adalah keadaan dalam pribadi seseorang yang mendorong keinginan individu untuk melakukan kegiatan-kegiatan tertentu untuk melakukan investasi (Pajar \& Pustikaningsih, 2017). Menurut penelitian (Nandar et al., 2018) motivasi investasi memberikan pengaruh kuat terhadap minat mahasiswa berinvestasi di pasar modal syariah, dan sejalan juga dengan penelitian Pajar \& Pustikaningsih (2017) motivasi investasi berpengaruh terhadap minat berinvestasi di pasar modal pada mahasiswa FE UNY.

Berdasarkan uraian di atas tujuan penelitian ini adalah untuk melihat lebih jauh mengenai pengaruh pengetahuan investasi, persepsi return, dan motivasi investasi terhadap minat investasi mahasiswa di pasar modal syariah melalui Galeri Investasi Syariah Bursa Efek Indonesia (BEI) Institut Agama Islam negeri (IAIN) Batusangkar.

\section{Metode Penelitian}

Penelitian ini merupakan penelitian kuantitatif, dengan menggunakan instrumen penelitian berupa kuisioner yang mengambil populasi dan sampel mahasiswa Akuntansi Syariah yang sudah menjadi investor pada Galeri Investasi Syariah BEI IAIN Batusangkar yaitu sebanyak 132 orang responden. 
Data diperoleh dari lembaran jawaban kuisioner yang sudah diisi oleh responden tentang variabel pengetahuan investasi, persepsi return, motivasi investasi dan minat investasi. Skala pengukuran menggunakan skala Likert yang terdiri dari lima kategori yaitu : (1) Sangat Tidak Setuju, (2) Tidak Setuju, (3) Ragu-Ragu, (4) Setuju, (5) Sangat Setuju.

\section{Hasil dan Pembahasan}

\section{Analisis Regresi Linear Berganda}

Analisis regresi linear berganda berlandaskan pada hubungan fungsional maupun hubungan kausal dari dua atau lebih variabel independen dengan satu variabel dependen. Pengujian ini dimaksudkan untuk menguji variasi suatu model regresi yang digunakan dalam menerangkan variabel bebas $(\mathrm{X})$ terhadap variabel terikat (Y) dengan cara menguji kemaknaan dari koefesien regresinya.

\section{Tabel 1}

Coefficients $^{\mathrm{a}}$

\begin{tabular}{|c|c|c|c|c|c|}
\hline \multirow[b]{2}{*}{ Model } & \multicolumn{2}{|c|}{$\begin{array}{l}\text { Unstandardi zed } \\
\text { Coefficients }\end{array}$} & $\begin{array}{l}\text { Standardized } \\
\text { Coefficients }\end{array}$ & \multirow[b]{2}{*}{$\mathrm{T}$} & \multirow[b]{2}{*}{ Sig. } \\
\hline & B & Std. Error & Beta & & \\
\hline $1 \quad($ Cons $\tan t)$ & 2.961 & 2.389 & & 1.239 & .218 \\
\hline $\mathrm{x} 1$ & .193 & .083 & .184 & 2.329 & .021 \\
\hline $\mathrm{x} 2$ & .215 & .164 & .097 & 1.311 & .192 \\
\hline $\mathrm{x} 3$ & .503 & .070 & .526 & 7.191 & .000 \\
\hline
\end{tabular}

Sumber: Pengolahan Data dengan SPSS

Berdasarkan tabel di atas maka dapat disajikan persamaan regresi linier berganda sebagai berikut:

$\mathrm{Y}=2,961+0,1931+0,215 \mathrm{X}_{2}+0,503 \mathrm{X}_{3}$

Dimana :

$\begin{array}{lll}\mathrm{Y} & = & \text { Minat investasi } \\ \mathrm{X}_{1} & = & \text { Pengetahuan investasi } \\ \mathrm{X}_{2} & = & \text { Persepsi return } \\ \mathrm{X}_{3} & = & \text { Motivasi investasi }\end{array}$

Dari persamaan regresi di atas, dapat dijelaskan sebagai berikut :

a. Variabel pengetahuan investasi $\left(\mathrm{X}_{1}\right)$ memiliki nilai positif yang berarti pengetahuan investasi memiliki pengaruh positif dan memberikan terhadap minat investasi mahasiswa sebesar 0,193 sehingga setiap peningkatan pengetahuan investasi maka akan meningkatkan minat investasi secara positif, begitu juga sebaliknya setiap penurunan pengetahuan investasi akan memberikan penurunan terhadap minat investasi.

b. Variabel persepsi return $\left(\mathrm{X}_{2}\right)$ memiliki nilai positif yang berarti persepsi return memiliki pengaruh positif dan memberikan kontribusi terhadap minat investasi 
mahasiswa sebesar 0,215 sehingga setiap peningkatan terhadap persepsi return yang akan diterima maka akan memberikan penambahan terhadap minat investasi, begitu juga sebaliknya setiap penurunan terhadap persepsi return yang diterima akan akan memberikan pengaruh terhadap penurunan minat investasi.

c. Variabel motivasi investasi $\left(\mathrm{X}_{1}\right)$ memiliki nilai positif sebesar 0,503 yang berarti motivasi investasi memiliki pengaruh positif dan memberikan kontribusi terhadap minat investasi sebesar 0,503 sehingga setiap peningkatan motivasi investasi maka akan memberikan peningkatan yang besar terhadap minat investasi, begitu juga sebaliknya setiap penurunan motivasi investasi akan akan memberikan penurunan terhadap minat investasi.

\section{Pengujian Secara Parsial (Uji t)}

Uji $\mathrm{t}$ dilakukan untuk mengetahui pengaruh masing-masing variabel independen (pengetahuan investasi, persepsi return dan motivasi investasi) terhadap variabel dependen (minat investasi).

Tabel 2

Coefficients $^{\mathrm{a}}$

\begin{tabular}{|c|c|c|c|c|c|c|}
\hline & \multirow[b]{2}{*}{ Model } & \multicolumn{2}{|c|}{$\begin{array}{c}\text { Unstandardi zed } \\
\text { Coefficients }\end{array}$} & $\begin{array}{l}\text { Standardized } \\
\text { Coefficients }\end{array}$ & \multirow[b]{2}{*}{$\mathrm{T}$} & \multirow[b]{2}{*}{ Sig. } \\
\hline & & $\mathrm{B}$ & Std. Error & Beta & & \\
\hline \multirow[t]{4}{*}{1} & $($ Cons tant $)$ & 2.961 & 2.389 & & 1.239 & .218 \\
\hline & $\mathrm{x} 1$ & .193 & .083 & .184 & 2.329 & .021 \\
\hline & $\mathrm{x} 2$ & .215 & .164 & .097 & 1.311 & .192 \\
\hline & $\mathrm{x} 3$ & .503 & .070 & .526 & 7.191 & .000 \\
\hline
\end{tabular}

Sumber: Pengolahan Data dengan SPSS

Dari Tabel 2. di atas dapat dijelaskan terhadap pengujian secara pasrsial terhadap hipotesis yakni sebagai berikut:

1) Hipotesis 1: Pengetahuan investasi berpengaruh secara signifikan terhadap minat berinvestasi

Hasil uji T menunjukkan bahwa nilai signifikansi pengetahuan investasi $\left(\mathrm{X}_{1}\right)$ sebesar 0,021 yang lebih kecil dari 0,05 dan nilai t-hitung sebesar 2,329 yang lebih besar dari nilai t-tabel yang sebesar 1,979. Hasil ini menunjukkan bahwa secara parsial pengetahuan investasi $\left(\mathrm{X}_{1}\right)$ berpengaruh signifikan terhadap minat investasi.

Hasil ini sama dengan penelitian Albab Al Umar dan Zuhri (2019) yang menunjukkan bahwa pengetahuan investasi berpengaruh signifikan terhadap minat mahasiswa untuk berinvestasi di pasar modal syariah. Serta penelitian Pajar \& Pustikaningsih (2017) yang menyatakan bahwa pengetahuan investasi berpengaruh terhadap minat berinvestasi di pasar modal pada mahasiswa FE UNY.

2) Hipotesis 2 : Persepsi return berpengaruh secara signifikan terhadap minat berinvestasi 
Hasil uji $\mathrm{T}$ menunjukkan bahwa nilai signifikansi persepsi return $\left(\mathrm{X}_{2}\right)$ sebesar 0,192 yang lebih besar dari 0,05 dan nilai t-hitung sebesar 1,311 yang lebih kecil dari nilai $t_{\text {-tabel }}$ sebesar 1,979. Hasil ini menunjukkan bahwa secara parsial persepsi return $\left(\mathrm{X}_{2}\right)$ tidak berpengaruh secara signifikan terhadap minat investasi, hal ini memberikan gambaran bahwa minat mahasiswa untuk berinvestasi tidak hanya semata-mata mengharapkan return yang akan diterima.

Hasil penelitian ini tidak sama dengan penelitian (Tandio \& Widanaputra, 2016) yang menyatakan bahwa persepsi return mempengaruhi minat investasi secara signifikan. Begitu juga dengan penelitian (Trisnatio \& Pustikaningsih, 2018) menunjukkan hasil bahwa ekspektasi return berpengaruh positif dan signifikan terhadap minat investasi saham.

Tetapi hasil ini sama dengan penelitian yang dilakukan oleh (Purboyo et al., 2019) yang menunjukkan hasil bahwa persepsi return tidak berpengaruh signifikan terhadap minat mahasiswa untuk berinvestasi di saham syariah. Begitu juga dengan penelitian (Nandar et al., 2018) return investasi tidak memberikan pengaruh yang signifikan terhadap minat mahasiswa dalam berinvestasi di pasar modal syariah.

3) Hipotesis 3 : Motivasi investasi berpengaruh secara signifikan terhadap minat berinvestasi

Hasil uji T menunjukkan bahwa nilai signifikansi motivasi investasi $\left(\mathrm{X}_{3}\right)$ sebesar 0,000 yang lebih kecil dari 0,05 dan nilai t-hitung sebesar 7,191 lebih besar dari nilai t-tabel yang sebesar 1,979. Hasil ini menunjukkan bahwa secara parsial motivasi investasi $\left(\mathrm{X}_{3}\right)$ berpengaruh sangat signifikan terhadap minat investasi.

Hasil ini sesuai dengan penelitian (Nandar et al., 2018) motivasi investasi memberikan pengaruh kuat terhadap minat mahasiswa berinvestasi di pasar modal syariah, dan sejalan juga dengan penelitian Pajar \& Pustikaningsih (2017) bahwa motivasi investasi berpengaruh terhadap minat berinvestasi di pasar modal pada mahasiswa FE UNY.

\section{Pengujian Secara Simultan (Uji F)}

Uji F pada dasarnya menunjukkan apakah semua variabel independen yang dimasukkan dalam model mempunyai pengaruh secara bersama-sama terhadap variabel dependennya.

Tabel 3

ANOVA $^{\mathrm{a}}$

\begin{tabular}{llrrrrr}
\hline Model & Sum of Squares & Df & Mean Square & F & \multicolumn{1}{c}{ Sig. } \\
\hline 1 & Regression & 639.203 & 3 & 213.068 & 33.657 & $.000^{\mathbf{b}}$ \\
Residual & 810.312 & 128 & 6.331 & & \\
Total & 1449.515 & 131 & & & \\
\hline
\end{tabular}

Sumber: Pengolahan Data dengan SPSS 
Hipotesis 3 : Motivasi investasi berpengaruh secara signifikan terhadap minat berinvestasi

Hasil uji $\mathrm{F}$ menunjukkan bahwa variabel independen (pengetahuan investasi, persepsi return, dan motivasi investasi) memiliki pengaruh yang signifikan terhadap variabel dependen (minat investasi). Hal ini dibuktikan dari nilai signifikansi yang diperoleh sebesar 0,000 jauh lebih kecil dari 0,05. Hasil ini menunjukkan bahwa secara simultan variabel independen (pengetahuan investasi, persepsi return, dan motivasi investasi) berpengaruh sangat signifikan terhadap minat investasi mahasiswa di Galeri Investasi Syariah Bursa Efek Indonesia (BEI) Institut Agama Islam Negeri (IAIN) Batusangkar.

\section{Uji Koefisien Determinas $\left(\mathbf{R}^{2}\right)$}

Koefisien determinasi digunakan untuk mengetahui seberapa jauh pengaruh variabel $\mathrm{X}$ (pengetahuan investasi, persepsi return dan motivasi investasi) terhadap Y (minat investasi). Persentase pengaruh semua variabel bebas atas nilai variabel terikat ditunjukan oleh besarnya nilai Adjusted R Square.

\section{Tabel 4}

Model Summary

\begin{tabular}{llrrr}
\hline Model & R & R Square & Adjusted R Square & Std. Error of the Estimate \\
\hline 1 & $.664^{\mathrm{a}}$ & .441 & .428 & 2.51606 \\
\hline
\end{tabular}

Sumber: Pengolahan Data dengan SPSS

Dari tabel di atas diketahui nilai $\mathrm{R}$ Square $=0,441$, atau sama dengan 44,1\%. Angka tersebut berarti bahwa pengetahuan investasi, persepsi return dan motivasi investasi berpengaruh terhadap minat investasi mahasiswa di Pasar Modal Syariah melalui Galeri Investasi Syariah Bursa Efek Indonesia (BEI) IAIN Batusangkar sebesar $44,1 \%$. Sedangkan sisanya sebesar $55,9 \%$ dipengaruhi oleh variabel-variabel lain yang tidak diteliti dalam penelitian ini.

\section{Kesimpulan}

Berdasarkan hasil penelitian dapat disimpulkan bahwa secara parsial pengetahuan investasi dan motivasi investasi memiliki pengaruh yang signifikan terhadap minat investasi mahasiswa pada Galeri Investasi Syariah BEI IAIN Batusangkar, hal ini didukung oleh pelaksanaan kegiatan edukasi dan literasi yang dilakukan oleh Galeri Investasi Syariah BEI IAIN Batusangkar sehingga meningkatkan pengetahuan dan memberikan motivasi investasi yang dapat mendorong minat investasi mahasiswa. Sedangkan faktor persepsi return tidak berpengaruh signifikan terhadap minat investasi mahasiswa pada Galeri Investasi Syariah BEI IAIN Batusangkar, hal ini menggambarkan bahwa mahasiswa dalam melakukan investasi di pasar modal syariah tidak terlalu dipengaruhi oleh return (pengembalian) yang akan diterima dari investasi yang dilakukan. 


\section{BIBLIOGRAFI}

Nandar, H., Rokan, M. K., \& Ridwan, M. (2018). Faktor yang Mempengaruhi Minat Mahasiswa Berinvestasi di Pasar Modal Syariah Melalui Galeri Investasi Iain Zawiyah Cot Kala Langsa. KITABAH: Jurnal Akuntansi Dan Keuangan Syariah.

Pajar, R. C., \& Pustikaningsih, A. (2017). Pengaruh Motivasi Investasi dan Pengetahuan Investasi terhadap Minat Investasi di Pasar Modal pada Mahasiswa FE UNY. Jurnal Profita: Kajian Ilmu Akuntansi, 5(1).

Purboyo, P., Zulfikar, R., \& Wicaksono, T. (2019). Pengaruh Aktifitas Galeri Investasi, Modal Minimal Investasi, Persepsi Resiko Dan Persepsi Return Terhadap Minat Investasi Saham Syariah (Studi pada Mahasiswa Uniska MAB Banjarmasin). JWM (Jurnal Wawasan Manajemen), 7(2), 136-150.

Situmorang, M., Andreas, A., \& Natariasari, R. (2014). Pengaruh Motivasi terhadap Minat Berinvestasi di Pasar Modal dengan Pemahaman Investasi dan Usia sebagai Variabel Moderate. Riau University.

Sutira, A. (2018). Pengaruh struktur aktiva, struktur modal dan profitabilitas terhadap nilai perusahaan di PT. Jasuindo Tiga Perkasa Periode 31 Maret 2008-31 Desember 2016: Perusahaan yang Terdaftar di Jakarta Islamic Index. UIN Sunan Gunung Djati Bandung.

Tandio, T., \& Widanaputra, A. A. G. P. (2016). Pengaruh pelatihan pasar modal, return, persepsi risiko, gender, dan kemajuan teknologi pada minat investasi mahasiswa. E-Jurnal Akuntansi, 2316-2341.

Trisnatio, Y. A., \& Pustikaningsih, A. (2018). Pengaruh Ekspektasi Return, Persepsi Terhadap Risiko, Dan Self Efficacy Terhadap Minat Investasi Saham Mahasiswa Fakultas Ekonomi Universitas Negeri Yogyakarta. Jurnal Profita: Kajian Ilmu Akuntansi, 6(3).

Yuliana, I. (2010). Investasi Produk Keuangan Syariah. UIN-Maliki Press. 